\title{
Research on Credit Risk of Corporate Bond
}

\author{
Yani WEI \\ School of Economics and Management \\ Northwest University \\ Xi'an 710127, China \\ e-mail: weiyani0228@163.com
}

\author{
Zhangyong XU \\ School of Economics and Management \\ Northwest University \\ Xi'an 710127, China \\ e-mail: xzhangy@126.com
}

\begin{abstract}
Corporate bond is an important way for enterprises to make direct financing, and to a certain extent, it can replace the bank credit financing, so as to alleviate the financing problem of enterprises. However, the credit risk of corporate bonds will hinder the financing of enterprises. Therefore, this paper studies the factors influencing the credit risk of corporate bonds and the mechanism of slow release mechanism to help enterprises to better control the credit risk of corporate bonds.
\end{abstract}

Keywords-corporate bonds; credit risk; influencing factors; slow release mechanism

\section{INTRODUCTION}

Corporate bond financing advantages theory that corporate bonds can reduce the risk of banking systems, maintaining a stable state financing structure. In the case of debt financing, the issuance of bonds can directly replace bank loans, can avoid the excessive dependence on banks brought about by the bad loan crisis. However, corporate bonds themselves also have a large risk - credit risk, if the company wants to smooth the financing through the bond, you must manage the credit risk. Corporate credit risk management mainly includes credit rating, risk measurement, credit enhancement, credit risk slow release and other aspects. Foreign corporate bond market started early, the relevant credit derivatives market is also more mature, in the corporate bond credit risk management research is also more perfect. However, it is necessary to learn from the experience of foreign countries and combine the actual situation of China's bond market to analyze the influencing factors of credit risk of corporate bonds. On this basis, we study how to release enterprises The credit risk of the bond. This can not only provide guidance and reference for the healthy and rapid development of China's bond market, but also enrich the relevant literature in theory.

\section{INFLUENCING FACTORS OF CREDIT RISK OF CORPORATE BOND}

\section{A. Enterprise Intrinsic Value and Corporate bonds Credit Risk}

The endogenous factors influencing the credit risk of corporate bonds mainly include the level of enterprise management and the maturity of bonds and so on. First of all, the level of enterprise management of the bonds directly affects the credit risk of corporate bonds. The management level of the enterprise directly determines the profitability of the issuing enterprise, and the size of the profitability determines the bond investors can recover the principal and interest. Anthony \& Lederman 1 finds that the fluctuation of asset value is the main factor affecting the credit spread by studying the influence of the value of the enterprise's asset on the credit risk of the enterprise bond. At the same time, the interest rate fluctuation is another important factor to determine the credit spread. Ericsson, Jacobs \& Oviedo2 through empirical tests found that financial leverage and risk premium are closely related. Zulkarnain Muhamad Sori \& Hasbullah Abd Jalil3 study found that the level of business management is not only reflected in the financial indicators, but also reflected in the credit rating. Dan Covitz \& Chris Downing4 found that the credit characteristics have a greater impact on the liquidity level than the influencing factors of corporate bond spreads by studying the impact of US short-term non-financial corporate bond spreads. Second, the maturity of the bond is also a major factor affecting the credit risk of corporate bonds. The longer the maturity of corporate bonds, the worse the liquidity, then the bond investors face the greater the credit risk. Ho \& Singer5,6 under the framework of the Merton model and found that the credit risk of corporate bonds will increase as the maturity of the bonds expires, and the amortization clause will reduce the credit risk of corporate bonds, The right will reduce the price of corporate bonds, thereby increasing the corporate bond credit risk.

\section{B. Macroeconomic Environment and Corporate bonds Credit Risk}

As the micro-subject of economic activities, the business activities of enterprises are affected by the macroeconomic environment, thus affecting the credit risk of corporate bonds. Macroeconomic changes brought about by the corporate bond credit risk belongs to the system is the risk, not easy to disperse.

The Altman7 study found that there was a negative correlation between actual GDP, money supply, S \& P index and credit spreads of corporate bonds, that is, the credit risk of corporate bonds would be low in the period of macroeconomic conditions. On this basis, Thomas C.Wilson8 has added the unemployment rate, GDP growth rate, long-term interest rate, exchange rate, government expenditure and the total savings rate of these indicators, the establishment of a measure of bond default probability 
Credit Portfolio View model. James 9 examines the relationship between credit spreads and economic cycles in US corporate bonds. The results show that the credit spread between corporate bonds at the Aaa and Baa grades of the recession period has widened and has been reduced during the period of economic expansion. Ronald B.10 Through the establishment of the stock market index model, the impact of the stock market volatility on credit spreads was investigated. It was found that the bond spreads were reduced and the credit spreads were compensated for the bond risk as the stock market fluctuated. Dbouk \& Kryzanowski11 found that the expected rate of change in GDP's expected rate of change and the expected rate of slope of the term structure are the main factors that affect the portfolio's credit spreads, and the volatility of default risk, market liquidity and returns is the credit spread that affects the portfolio of the important factors. Longstaff \& Schwartz12 proposed a two-factor model for regression analysis of corporate bond credit spreads. The results show that the credit spreads will decrease as the risk-free rate increases, and the rise in the value of the company's assets or equity will help reduce its exposure The possibility of defaulting borders. The study of Avramov, Jostova \& Philipov13 yields a numerical representation of the proportion of explanatory capacity, five-year Treasury bills interest rate this factor can explain the corporate bond credit spreads $28.63 \%$. Followed by the return on market value measured by net assets, which explains $18.25 \%$ of the corporate credit spreads.

\section{Information Asymmetry and Credit Risk of Corporate Bonds}

Traditional Western economics assumes that the information of buyers and sellers is completely symmetrical, but in real life, information asymmetry can be seen everywhere. As the external investors can not accurately understand the true financial situation of enterprises, do not know whether the company can repay the principal and interest on time, therefore, information asymmetry will inevitably lead to increased corporate credit risk. Duffie \& Lando14 is based on the assumption that the information provided by the enterprise is not perfect, so as to construct the valuation model to indirectly study the impact of information asymmetry on corporate bond credit risk. On the basis of this, Fan Yu15 used the AIMR disclosure level as the measure of the transparency of financial information, and studied the relationship between the term structure of corporate bond credit spread and the quality of financial information. The study found that companies with higher financial transparency have lower credit spreads.

\section{Slow Release of CORPORATE Bonds CREDIT RISK}

Through the above analysis, we find that the factors that affect the credit risk of corporate bonds are mainly the management level, the uncertainty of the macro environment and the information asymmetry. Among them, the credit risk of corporate bonds brought by the change of macroeconomic environment is systemic risk and is not easy to be scattered. The credit risk caused by management level and information asymmetry is non-systematic risk, which is easy to disperse and slow release. Next, we analyze the slow release of corporate bond credit risk from the three aspects of the principle of slow release of credit risk, slow release tool and slow release effect.

\section{A. Credit Risk Relief Principle}

Credit risk slow release refers to the use of financial institutions to monitor the use of credit risk mitigation tools, such as credit, pledge,

Guarantees and credit derivatives, etc., to transfer or reduce the credit risk of the relevant financial products. The concept of risk mitigation for the first time is "Basel II", and its specific definition of "Basel II", that credit risk mitigation is through the use of qualified collateral, net settlement, guarantee And credit derivatives, etc. to transfer or reduce credit risk. At the same time, it clarifies and expands the scope of qualified collateral and the guarantor, and makes clear stipulation and requirements on the capital requirements, risk weight, legal certainty and information disclosure of credit risk mitigation technology. The framework of credit risk mitigation is also being perfected continuously. The main contents include risk capital requirements, confirmation requirements, confirmation of slow release technology, confirmation of risk mitigation, credit after credit risk protection Calculation requirements and so on. At present, the internationally accepted credit risk mitigation tool trading standard agreement text for the "ISDA master agreement" and "ISDA credit derivatives definition document".

\section{B. Credit Risk Mitigation Tool}

Credit risk mitigation tool refers to credit risk mitigation contract, credit risk mitigation certificate and other simple basic credit derivative products used to manage credit risk, which can be traded, one to many, standardized, low leverage risk of credit risk Release contract and credit risk relief certificate. The commonly used corporate bond credit risk mitigation tools mainly include: secured debt document (CDO) and credit default swap (CDS).

CDO is an important part of the asset securitization family, is a fixed income securities, cash flow between the higher predictability, not only to provide investors with multiple investment channels and increase investment income, but also strengthened the financial institutions of the use of funds Efficiency, transfer uncertainty. Its underlying assets are usually credit assets or bonds. Through the corporate bonds to raise funds pooled groups, and then for asset packaging and segmentation, transferred to a special purpose carrier, private or public offering to sell fixed income securities or beneficiary vouchers.

CDS is the most common credit derivative product in the foreign bond market. It refers specifically to a contract that the buyer and the seller conducts risk conversion on the specified credit event within a certain period of time. In a credit default swap, a default swap buyer will periodically pay a fee for a default swap seller (called a credit default swap spread), and once a credit event (mainly the 
bondholder is unable to pay) Interchangeable buyers will have the right to deliver the bonds at face value to the default swap seller, thereby effectively evading credit risk.

\section{Credit Risk Mitigation Effect}

The vast majority of scholars believe that the rational use of credit risk mitigation tools can effectively spread and transfer credit risk. However, after the outbreak of the financial crisis in 2008, the academic community began to reflect the negative effects of credit risk mitigation

The use of credit risk mitigation tools can effectively transfer credit risk, improve market liquidity, and promote the development and deepening of financial markets. Duquerroy \& $\mathrm{Gex}^{16}$, $\mathrm{Cont}^{17}$ argues that credit risk mitigation tools can help commercial banks save costs, improve liquidity, provide more effective risk management, create new investment channels for institutional investors, and improve the efficiency of financial systems And stability. Zhang etal ${ }^{18}$ used asset securitization tools to consider the value of credit enhancement, which argues that there is a big difference in the cost and profitability of different credit enhancement methods for asset design of asset-backed securities structures. Taking into account the value of credit enhancement, you can control the credit by increasing the cost of the method to increase the selection and matching tools. Lai \& Soumare ${ }^{19}$ established a continuous or contingency analysis model to analyze the impact of credit insurance on investment and found that the existence of credit insurance greatly increased the attractiveness of investment under the premise of maximizing the interests of investors. Ely ${ }^{20}$ analyzes the situation of municipal bond insurance after the 2008 financial crisis, and argues that municipal bond insurance is a mechanism to alleviate investor concerns, especially in the post-crisis tax-free debt market.

The application of credit risk mitigation tool may also exacerbate the financial system risk, which has certain shortcomings in credit risk management, which aggravates the pursuit of investors' risk income and can easily lead to the transfer, transmission and accumulation of credit risk, The stability of the entire banking system has a certain destructive effect. Haensel \& Krahnen ${ }^{21}$ explored the impact of credit risk transfer tools on the risk of large international banks using a set of data from European CDOs, and found that credit securitization was closely linked to the risk appetite of issuers, CDOs tend to increase the systemic risk of issuing banks. Chuang et $\mathrm{al}^{22}$ studied the impact of providing private insurance for default risk premiums and discounted credit spreads using the contingent claim approach. They argue that, for new primary loans, even if financial insurance is comparable to that of AAA-level private insurers, the role of insurers in providing insurance to reduce the risk of default on loan defaults is limited; even if there are AAA private insurers Full insurance, loan default risk premium must also be able to reflect the intrinsic value of the insured and insurers' risk and the covariance between the two.

\section{REFERENCES}

[1] Anthony G Corning Robert A. Klein Jesse Lederman, Tang Xu et al., 1998: "Interest rate risk control and management", Economic Science Press.

[2] Ericsson, Jacobs\& Oviedo, 2005,"The determinants of credit default swap premia ", Working Paper.

[3] Sori \& Jalil, 2009,"Financial ratios discriminant analysis and the prediction of corporate distress", Journal of Money, Investment and Banking.

[4] Covitz \& Downing, 2007,"Liquidity or credit risk? The determinants of very short- term corporate yield spreads",The Journal of Finance.

[5] Ho \& Singer,"Bond indenture provisions and the risk of corporate debt", Journal of Financial Economics.1982, 10:375- 406.

[6] Ho \& Singer, "The value of corporate debt with a sinking-fund provision", Journal of Business .1984, 57:315-336.

[7] Altman, Corporate Financial Distress. 1990. New York:Wiley.

[8] Wilson, T.C. ,"Portfolio credit risk", 1998, Economic Policy Review.

[9] James C. Van Horn, Zhao Zhiwen, Yu Liang translation . "financial market interest rates and flow", 2000, Northeast University of Finance and Economics Press.

[10] Ronalad, David \& Paul,"The impact of stock market volatility on corporate bond credit spreads", Mathematics and Computers in Simulation, 2004, pp.363-372.

[11] Dbouk \& Kryzanowski ,"Determinants of credit spread changes", 2007, Working Paper of Concordia University.

[12] Longstaff \& Schwartz,"A simple approach to valuing risky fixed and floating rate debt",1995, The Journal of Finance.

[13] Avramov, Jostova \& Philipov ,"Understanding changes in corporate credit spreads", Financial Analysts Journal.2007, 63:90- 105.

[14] Duffee ,"The relation between treasury yields and corporate bond yield spreads", 1998, The Journal of Finance.

[15] Yu, Fan,"Accounting transparency and the term structure of credit spreads", 2003,The Jounal of Finance.

[16] Duquerroy, A. \& M. Gex, "Credit default swaps and financial stability: Risks and regulatory issues",The Future of Financial Regulation .2009,13(9):21-25.

[17] Cont, R.,"Credit default swaps and financial stability", Financial Innovation and Stability.2010, 14(7):8-12

[18] Zhang, Dedong etal , "The contribution quantity of credit enhancement of financial instruments with asset-backed securitization structure ", Business Intelligence and Financial Engineering . 2009. 7:686-690.

[19] Lai, V.S. \& I. Soumare,"Credit insurance and investment: A contingent claims analysis approach ", International Review of Financial Analysis . 2010. 19(2):98-107

[20] Ely, T.L. , "No guaranties: The decline of municipal bond insurance ", Public Budgeting and Finance. 2012. 32(1): 105-127.

[21] Haensel, D.\& J.P. Krahnen ," Dose credit securitization reduce bank risk? Evidence from the European CDO market", 2007. Goethe University Working paper.

[22] Chuang etal "Credit enhancement and loan default risk premiums", Canadian Journal of Administrative Sciences.2009.(3):301-312. 